\title{
PENGEMBANGAN PELATIHAN BERBASIS \\ INSTRUCTIONAL SISTEM DEVELOPMENT MODEL (ISD) \\ BAGI PENYULUH PERTANIAN LAPANGAN \\ DI KABUPATEN MALANG
}

\section{TRAINING DEVELOPMENT BASED ON INSTRUCTIONAL SISTEM DEVELOPMENT MODEL (ISD) \\ FOR AGRICULTURAL EXTENSION WORKERS IN MALANG REGENCY}

\author{
Wahyu Windari dan Gunawan \\ Politeknik Pembangunan Pertanian Malang \\ e-mail: wahyu_windari@yahoo.com
}

\begin{abstract}
ABSTRAK
Studi literatur ini ditulis dalam rangka merancang penelitian berbasis ISD untuk mewujudkan perencanaan pelatihan yang baik yang diharapkan dapat menghasilkan kompetensi sesuai yang diinginkan. Tulisan ini didasarkan pada permasalah penyuluh yang sangat antusias terhadap pendekatan penyuluhan partisipatif dan memahami pentingnya perlibatan masyarakat petani dalam kegiatan penyuluhan, namun demikian penyuluh merasa bahwa penerapan partisipasi dalam kegiatan penyuluhan tidak terjadi. Hal ini dikarenakan petani tidak merasa perlu untuk berpartisipasi dan menganggap partisipasi yang dilakukan membuang waktu mereka. Penyuluh merasa kurang mempunyai ketrampilan dalam berkomunikasi untuk meyakinkan petani akan pentingnya partisipasi dalam proses penyuluhan. Untuk meningkatkan kompetensi tersebut perlu disusun model pelatihan berbasis ADDIE. Model ini dipilih karena mempunyai langkah yang sederhana, mudah diterapkan tetapi mewakili keseluruhan proses system pembelajaran. Model pengembangan model pembelajaranADDIE dari lima fase yaitu, Analyze, Design, Develop, Implement, dan Evaluate. Keseluruhan tahapan yang ada pada model ADDIE dapat di implementasikan atau digunakan dalam program pelatihan untuk upaya meningkatkan ketrampilan komunikasi dan teknik fasilitasi yang dirasakan kurang bagi PPL di Kabupaten untuk meyakinkan petani akan pentingnya partisipasi petani dalam proses penyuluhan.
\end{abstract}

Kata Kunci : Pelatihan berbasis ISD, PPL, komunikasi

\section{ABSTRACT}

This literature study was written in order to design ISD-based research to realize good training planning that is expected to produce competencies as desired. This paper is based on the problem of counselors who are very enthusiastic about the participatory extension approach and understand the importance of involving farmers in extension activities, however extension workers feel that the implementation of participation in extension activities does not occur. This is because farmers do not feel the need to participate and assume that participation is a waste of their time. Extension workers feel that they lack communication skills to convince farmers of the importance of participation in the extension process. To improve this competency, it is necessary to develop an ADDIE based training model. This model was chosen because it has simple steps, is easy to implement but represents the whole process of the learning system. The ADDIE 
learning model development model consists of five phases namely, Analyze, Design, Develop, Implement, and Evaluate. The entire stages in the ADDIE model can be implemented or used in training programs to improve communication skills and facilitation techniques that are felt to be lacking for extension workers in the District to convince farmers of the importance of farmer participation in the extension process.

Keywords: ISD Based Training, Agricultural Extension Workers, Communication

\section{PENDAHULUAN}

\section{Latar belakang}

MEA (Masyarakat Ekonomi ASEAN) atau AEC (Asean Economic Community) adalah bentuk kerjasama ekonomi regional asia tenggara dengan tujuan utama MEA adalah menjadikan ASEAN sebagai pasar tunggal dan basis produksi dimana terjadi arus barang, jasa, investasi, dan tenaga terampil yang bebas serta aliran modal yang lebih bebas yang dicanangkan dan disepakati mulai diberlakukan pada Desember 2015. Implikasi penerapan AEC 2015 di Indonesia adalah akan semakin banyaknya barang impor yang masuk ke Indonesia dimana asalnya adalah dari negara-negara ASEAN. Indonesia yang termasuk didalamnya harus waspada dengan diberlakukannya MEA. Peranan pemerintah sangat diperlukan melalui program dan kebijakan bagi masyarakat Indonesia di banyak sektor kehidupan, khususnya sektor pertanian. Dalam menghadapi MEA sektor pertanian harus juga dipersiapkan mengingat sebagian besar rakyat Indonesia bergerak di bidang pertanian yang dapat berimbas pada kehidupan petani dalam meningkatkan kesejahteraannya.

Sektor pertanian hingga kini masih memiliki peranan yang strategis dalam pembangunan nasional, baik bagi pertumbuhan ekonomi maupun pemerataan pembangunan. Peran strategis sektor pertanian bagi pertumbuhan ekonomi antara lain: penyedia pangan bagi penduduk Indonesia, penghasil devisa negara melalui ekspor, penyedia bahan baku industri, peningkatan kesempatan kerja dan usaha, peningkatan PDB, pengentasan kemiskinan dan perbaikan SDM pertanian melalui 58 | Jurnal Agriekstensia Vol. 18 No. 1 Juli 2019 kegiatan Penyuluhan Pertanian (Kementan, 2008). Penyuluhan pertanian sebagai bagian dari sistem pembangunan pertanian mempunyai kedudukan yang sangat strategis dalam pembangunan pertanian. Hal ini dibutktikan dengan keseriusan pemerintah dalam menata sistim penyuluhan pertanian melalui Revitalisasi Penyuluhan Pertanian. Revitalisasi pertanian ini dimaksudkan sebagai upaya pembangunan pertanian dengan cara yang lebih partisipatif, untuk menumbuhkan komitmen dan kerjasama seluruh stake holder serta adanya perubahan paradigma masyarakat dalam memandang sektor pertanian (Jamal dalam Yusran, 2006).

Salah satu mandat perubahan pola penyuluhan adalah penyuluhan pertanian partisipatif dimana penyuluhan partisipatif merupakan metode penyuluhan yang lebih terbuka dengan sistem -bottom-up dan pelibatan petani secara penuh. Partisipatif menurut Chambers adalah partisipasi dalam arti bahwa masyarakat terlibat langsung dalam setiap tahapan proses. Hal ini mengindikasikan bahwa partisipasi berorientasi kepada pemberdayaan petani sehingga mampu menyelesaikan masalahnya sendiri atau mampu mengambil kebijakan untuk masa depannya sendiri. Petani secara penuh harus terlibat dalam seluruh proses, mulai dari perencanaan (planning), pengorganisasian (organizing), pelaksanaan (actuating) sampai kepada pengawasan (monitoring) dan evaluasi (evaluation). Penyuluhan pertanian partisipatif dimaksudkan untuk meningkatkan partisipasi dan kemandirian dari petani sendiri untuk melaksanakan kegiatan penyuluhan partisipatif dalam mengelola usaha taninya. Tingkat partisipasi petani dalam kegiatan penyuluhan akan 
mempengaruhi tingkat pemahaman dan adopsi petani terhadap perkembangan baru sektor pertanian. Dalam Penyuluhan pertanian partisipatif diterapkan prinsipprinsip partisipatif yang memberdayakan petani secara maksimal tidak hanya sebagai pendengar tetapi juga sebagai nara sumber sekaligus.

Dalam menyelenggarakan kegiatan penyuluhan partisipatif, kemampuan berkomunikasi dalam proses penyampaian pesan kepada petani untuk memajukan usahanya merupakan tanggung jawab besar yang diemban seorang penyuluh. Hal ini sesuai dengan pernyataan Kartasapoetra (1994) yang menyatakan penyuluh pertanian merupakan agen bagi perubahan perilaku petani, yaitu mendorong petani mengubah perilakunya menjadi petani dengan kemampuan yang lebih baik dan mampu mengambil keputusan sendiri, yang selanjutnya akan memperoleh kehidupan yang lebih baik. Melalui peran penyuluh, petani diharapkan menyadari akan kebutuhannya, melakukan peningkatan kemampuan diri, dan dapat berperan di masyarakat dengan lebih baik.

Agar kegiatan penyuluhan sebagai proses penyampaian pesan dapat berjalan fektif dan efisien, penyuluh sebagai seorang agen pembaharu harus memperhatikan unsur komunikasi yaitu bagaimana menyampaikan pesan dan memperhatikan penerima pesan disertai dengan pemilihan media dan bagaimana mengemas pesan. Sebaik apapun pengirim pesan dalam menyampaikan informasi akan sangat tergantung dari bagaimana respon, persepsi dan antusiassme penerima pesan itu sendiri dalam menerima informasi yang disampaikan.

Dari hasil penelitian yang dilakukan oleh Agunga (2016) dalam jurnal yang berjudul " Challenges Facing Extension Agents in Implementing the Participatory Extension Approach in Indonesia: A Case Study of Malang Regency in the East Java Region". Dapat ditarik kesimpulan bahwa penyuluh pertanian di Kabupaten Malang sangat antusias terhadap pendekatan penyuluhan partisipatif dan memahami 59 | Jurnal Agriekstensia Vol. 18 No. 1 Juli 2019 pentingnya pelibatan masyarakat petani dalam kegiatan penyuluhan, namun demikian penyuluh merasa bahwa penerapan partisipasi dalam kegiatan penyuluhan tidak terjadi. Hal ini dikarenakan petani tidak merasa perlu untuk berpartisipasi dan menganggap partisipasi yang dilakukan membuang waktu mereka. Dan yang terpenting adalah bahwa penyuluh merasa kurang mempunyai ketrampilan dalam berkomunikasi untuk meyakinkan petani akan pentingnya partisipasi dalam proses penyuluhan. Hal ini merupakan tantangan tersendiri bagi PPL di Kabupaten Malang untuk meningkatkan kompetensi mereka dalam berkomunikasi dan bagaimana teknik fasilitasi sehingga dapat mengajak petani untuk turut berpartisipasi dalam kegiatan penyuluhan. Dari latar belakang kondisi penyuluh di Kabupaten Malang maka perlu dirumuskan bagaimana merencanakan model pelatihan bagi penyuluh yang efektif dan efisien tentang communication skill dan teknik fasilitasi untuk meyakinkan petani pentingnya partisipasi petani dalam kegiatan penyuluhan.

\section{Tujuan}

Menetapkan model pelatihan yang efektif dan efisien bagi para penyuluh di Kabupaten Malang tentang ketrampilan berkomunikasi dan teknik fasilitasi dalam rangka meyakinkan petani pentingnya partisipasi petani dalam kegiatan penyuluhan pertanian.

\section{Kegunaan}

Model pelatihan yang disusun diharapkan dapat bermanfaat bagi peningkatan ketrampilan komunikasi dan teknik fasilitasi bagi penyuluh di Kabupaten Malang sehingga pemahaman dan adopsi petani dalam menerima inovasi baru dapat ditingatkan.

\section{PENDEKATAN PELATIHAN}

Nadler dan Wiggs (dalam Achmat, 2010) mendefinisikan pelatihan (training) sebagai teknik-teknik yang memusatkan 
pada belajar tentang ketrampilanketrampilan, pengetahuan dan sikap-sikap yang dibutuhkan untuk memulai suatu pekerjaan atau tugas-tugas atau untuk meningkatkan kemampuan dalam melakukan suatu pekerjaan atau tugas. Dalam merencanakan kegiatan pelatihan diperlukan kecermatan untuk mendapatkan hasil yang maksiml dalam proses pelatihan. Terdapat banyak model pelatihan yang telah dikembangkan oleh beberapa ahli dibidang pengembangan Sumberdaya Manusia seperti Mayo dan Du Bois (1987), Goad, (1982), Nedler (1982) dengan The Critical Events model (CEM), Morrison, Ross dan Kemp (2004), model ADDIE dari Molenda (2003), dan ahli lainnya telah menyajikan berbagai jenis model pelatihan dengan asumsi dan kekhasan masing-masing.

\section{Model Pelatihan yang dipilih}

$$
\text { Model pelatihan system }
$$

pengembangan pembelajaran Instruksional

System Development Model yang sering disebut juga sebagai ADDIE dipilih karena sederhana dan mudah dilakukan tetapi terstruktur dan sistematis. ISD dapat dianggap sebagai roadmap yang membantu untuk memastikan peserta didik dan organisasinya untuk mencapai tujuan belajar dan kinerja mereka melalui formal, nonformal, dan informal. Model ini terdiri dari lima fase atau tahap utama, yaitu: 1 . yaitu Analysis (analisis), Design (desain), Development (pengembangan), Implentation (implementasi), dan Evaluation (evaluasi). Sebagai gambaran, berikut disampaikan skema model ISD atau sering disebut juga model ADDIE beserta penjelasan pada setiap tahapannya.

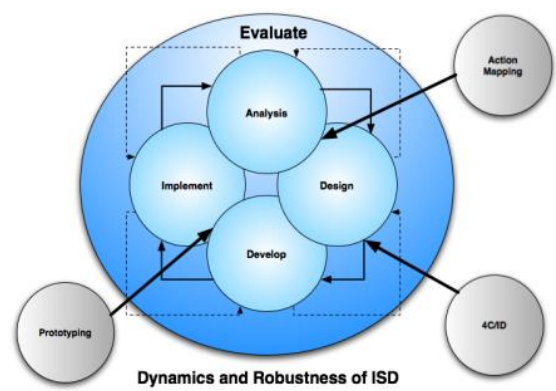

Gambar 1. Skema Model ISD

60 | Jurnal Agriekstensia Vol. 18 No. 1 Juli 2019

\section{Tahap Analisis (Analisys)}

Analisis merupakan langkah pertama dari model desain sistem pembelajaran ADDIE.

Langkah analisis melalui dua tahap yaitu:

\section{a. Analisis Kinerja}

Analisis Kinerja dilakukan untuk mengetahui dan mengklarifikasi apakah masalah kinerja yang dihadapi memerlukan solusi berupa penyelenggaraan program pembelajaran atau perbaikan manajemen.

\section{b. Analisis Kebutuhan}

Analisis kebutuhan merupakan langkah yang diperlukan untuk menentukan kemampuan-kemampuan atau kompetensi yang perlu untuk meningkatkan kinerja. Hal ini dapat dilakukan apabila program pembelajaran dianggap sebagai solusi dari masalah pembelajaran yang sedang dihadapi. Analisis kebutuhan adalah dalam rangka mencari apakah tujuan pembelajaran yang telah ditentukan, dibutuhkan oleh peserta, 2)

Apakah tujuan pembelajaran yang telah ditentukan, dapat dicapai oleh peserta, 3) Bagaimana karakteristik peserta yang akan mengikuti program pembelajaran, 4) Pengetahuan dan ketrampilan seperti apa yang telah dimiliki oleh peserta , 5)

Kemampuan atau kompetensi apa yang perlu dimiliki oleh peserta, 6) penetapan indikator atau kriteria yang dapat digunakan untuk menentukan bahwa peserta telah mencapai kompetensi yang telah ditentukan setelah melakukan pembelajaran, 7) penetapan indikator kompetensi peserta setelah mengikuti proses pelatihan.

\section{Desain}

Desain merupakan langkah kedua dari model desain sistem pembelajaran ADDIE. Langkah ini merupakan Inti dari langkah analisis karena mempelajari masalah kemudian menemukan alternatif solusinya yang berhasil diidentifikasi melalui langkah analisis kebutuhan. Tahap desain terkait dengan penentuan sasaran, instrumen penilaian, latihan, konten, dan analisis yang terkait materi pembelajaran, rencana pembelajaran dan pemilihan media. Fase desain dilakukan secara sistematis dan 
dengan kemampuan yang seharusnya dimiliki peserta pelatihan.

\section{Pengembangan}

Pengembangan merupakan langkah ketiga dalam mengimplementasikan model desain sistem pembelajaran ADDIE. Langkah pengembangan meliputi kegiatan membuat, membeli, dan memodifikasi bahan ajar. Dengan kata lain mencakup kegiatan memilih, menentukan metode, media serta strategi pembelajaran yang sesuai untuk digunakan dalam menyampaikan materi atau substansi program.

\section{Implementasi}

Fase ini, dibuat prosedur untuk pelatihan bagi peserta pelatihan dan instrukturnya/ fasilitator. Pelatihan bagi fasilitator meliputi materi kurikulum,hasil pembelajaran yang diharapkan, metode penyampaian dan prosedur pengujian. Aktivitas lain yang harus dilakukan pada fase ini meliputi penggandaan dan pendistribusian materi dan bahan pendukung lainnya, serta persiapan jika terjadi masalah teknis dan mendiskusikan rencana alternatif dengan peserta.

\section{Tahap evaluasi (Evaluation)}

Setiap tahap proses ADDIE melibatkan evaluasi formatif. Ini adalah multidimensional dan merupakan komponen penting dari proses ADDIE. Ini mengasumsikan bentuk evaluasi formatif dalam tahap pengembangan. Evaluasi dilakukan selama tahap implementasi dengan bantuan instruktur dan peserta pelatihan. Setelah pelaksanaan pembelajaran selesai, evaluasi sumatif dilakukan untuk perbaikan pembelajaran. Perancang seluruh tahap evaluasi harus memastikan apakah masalah yang relevan dengan program pelatihan diselesaikan dan apakah tujuan yang diinginkan.

\section{Rencana Pelatihan}

Rencana pelatihan yang disusun dengan materi komunikasi efektif dan teknik fasilitasi adalah hasil analisis kebutuhan pelatihan bagi PPL didasarkan pada pengamatan Tabel 4 jurnal hasil penelitian Cahyono (2016) tentang Challenges Facing Extension Agents in Implementing the Participatory Extension Approach in Indonesia: A Case Study of Malang Regency in the East Java Region". Dari Tabel tersebut terlihat bahwa secara rata-rata sekitar $85 \%$ PPL setuju pentingnya partisipasi petani dalam kegiatan penyuluhan. Namun demikian PPL merasa kesulitan mengajak petani untuk berperan serta dalam kegiatan penyuluhan sehingga diperlukan pelatihan tentang komunikasi efektif dan teknik fasilitasi bagi PPL.

Dari Analisis kebutuhan ditetapkan materi pelatihan dengan tujuan pelatihan disertai penetapan metode media dan indikator pencapaian tujuan pembelajaran sebagaimana ditunjukkan pada table 1 berikut:

Tabel 1. Materi dan tujuan pelatihan, metode, media dan indikator pencapaian tujuan pembelajaran

\begin{tabular}{|c|c|c|c|c|c|c|c|}
\hline No. & Materi & Tujuan & Inf.Pokok & Metode & Media & Indikator & waktu \\
\hline 1 & $\begin{array}{l}\text { Pendidikan } \\
\text { Orang } \\
\text { Dewasa }\end{array}$ & $\begin{array}{l}\text { Setelah mengikuti Pelatihan } \\
\text { peserta dapat menjelaskan } \\
\text { perbedaan Andragogi } r \text { dan } \\
\text { Paedagogi dalam } \\
\text { pembelajaran }\end{array}$ & $\begin{array}{l}\text { Andragogi } \\
\text { dan Pedagogi }\end{array}$ & Diskusi & LCD & $\begin{array}{lr}\text { Peserta } & \text { dapat } \\
\text { menyebut } & \\
\text { menjelaskan } & \text { perbe } \\
\text { daan } & \text { PBM } \\
\text { paedagogi } & \text { dan } \\
\text { andragodi } & \end{array}$ & $150^{\prime}$ \\
\hline 2 & $\begin{array}{l}\text { Dasar } \\
\text { Komunikasi }\end{array}$ & $\begin{array}{l}\text { Setelah mengikuti Pelatihan } \\
\text { peserta dapat : }\end{array}$ & $\begin{array}{l}\text { Macam } \\
\text { bentuk }\end{array}$ & Diskusi & $\begin{array}{l}\text { Lembar } \\
\text { bermain } \\
\text { LCD }\end{array}$ & $\begin{array}{l}\text { Peserta dapat } \\
\text { menyebut jenis dan }\end{array}$ & 50 \\
\hline
\end{tabular}




\begin{tabular}{|c|c|c|c|c|c|c|c|}
\hline & & $\begin{array}{l}\text { - Menjelaskan jenis } \\
\text { komunikasi } \\
\text { - menjelaskan pengertian } \\
\text { komunikasi multi arah } \\
\text { - Tata Cara membangun } \\
\text { komunikasi } \\
\text { - Komunikasi efektif }\end{array}$ & $\begin{array}{l}\text { komuikasi, } \\
\text { pengertian } \\
\text { komunikasi } \\
\text { dan } \\
\text { komunikasi } \\
\text { efektif }\end{array}$ & $\begin{array}{l}\text { Studi } \\
\text { kasus }\end{array}$ & & $\begin{array}{l}\text { macam komunikasi, } \\
\text { komunikasi efektif }\end{array}$ & 150 \\
\hline 3 & Fasilitasi & $\begin{array}{l}\text { Setelah mengikuti Pelatihan } \\
\text { peserta dapat : menjelaskan } \\
\text { pendekatan fasilitasi, terampil } \\
\text { membangun kelompok dan } \\
\text { mampu menetapkan media dan } \\
\text { metode fasilitasi }\end{array}$ & $\begin{array}{l}\text { Fasilitasi, } \\
\text { Pengertian } \\
\text { Kelompok } \\
\text { Pemilihan } \\
\text { Media dan } \\
\text { Metode } \\
\text { Pelatihan }\end{array}$ & $\begin{array}{l}\text { Tanya } \\
\text { jawab } \\
\text { diskusi } \\
\text { dan } \\
\text { permain } \\
\text { an }\end{array}$ & $\begin{array}{l}\text { Lembar } \\
\text { permain } \\
\text { an LCD }\end{array}$ & $\begin{array}{l}\text { Peserta dapat } \\
\text { mengidentifikasi } \\
\text { pendekatan } \\
\text { fasilitasi, } \\
\text { menetapkan materi } \\
\text { dan media PBM, } \\
\text { membuat kelompok }\end{array}$ & $150^{\prime}$ \\
\hline 4 & $\begin{array}{l}\text { Berlatih } \\
\text { Memfasili } \\
\text { tasi }\end{array}$ & $\begin{array}{lrr}\text { Setelah mengikuti } & \text { proses } \\
\text { platihan peserta } & \text { dapat } \\
\text { melakukan persiapan dan } \\
\text { trampil dalam melakukan } \\
\text { fasilitasi petani }\end{array}$ & $\begin{array}{l}\text { Teknik } \\
\text { fasilitasi }\end{array}$ & $\begin{array}{l}\text { Praktek } \\
\text { memfasi } \\
\text { litasi }\end{array}$ & $\begin{array}{l}\text { LCD } \\
\text { Lembar } \\
\text { fasilitasi }\end{array}$ & $\begin{array}{l}\text { Peserta dapat } \\
\text { melakukan fasilitasi } \\
\text { petani }\end{array}$ & $\begin{array}{l}8 \text { jam } \\
\text { @ } 50 \\
\text { menit }\end{array}$ \\
\hline
\end{tabular}

Pelaksanaan pelatihan sebagai implementasi analisis kebutuhan latihan dan perencanaan berupa kegiatan pelatihan yang direncakana akan dilaksanakan selama 5 hari dengan cakupan materi sebagaimana disebutkan pada Tabel di atas. Evaluasi sebagai aknhir kegiatan pelatihan juga dilakukan untuk melihat sejauhmana tujuan pelatihan dapat tercapai dan apakah pelatihan yang disusun dapat memenuhi kekurangan kompetensi yang dimilki peserta pelatihan.

\section{Analisis dan Pembahasan Model dan Rencana Pelatihan}

Model yang digunakan dalam pelatihan ini adalah model ADDIE. (Mengapa menggunakan ADDIE atau ISD? Secara sederhana, model ini menyediakan sarana untuk pengambilan keputusan suara untuk menentukan siapa, apa, kapan, di mana, mengapa, dan bagaimana program pembelajaran. Konsep pendekatan sistem didasarkan pada mendapatkan gambaran menyeluruh dari proses pembelajaran. Hal ini ditandai dengan proses yang teratur untuk mengumpulkan dan menganalisis persyaratan kinerja kolektif dan individu, dan kemampuan untuk merespon diidentifikasi pembelajaran dan pelatihan kebutuhan. Penerapan pendekatan sistem menjamin bahwa belajar program dan bahanbahan pendukung yang diperlukan secara terus menerus dikembangkan secara efektif dan efisien sesuai dengan berbagai kebutuhan dalam lingkungan yang berubah dengan cepat. (Branson, 1978)

Model ADDIE dirasa tepat dalam merancang pelatihan bagi PPL tentang kemampuan berkomunikasi efektif dan teknik fasilitasi. Training Needs Assessment dilakukan sebagai langkah awal dari model ADDIE . Komunikasi Efektif dan Teknik Analisis merupakan materi yang dipilih. Asumsinya adalah dengan mempertimbangkan kebutuhan peserta maka proses pelatihan selanjutnya akan berjalan lancar karena peserta menganggap penting materi yang diperlukan sehingga termotivasi untuk hadir dan antusias dalam mengikuti pelatihan. Dengan motivasi yang tinggi selama mengikuti pelatihan diharapkan adopsi materi cepat terserap sehingga kemampuan dalam berkomunikasi efektif dan teknik fasilitasi dapat meningkat pula.

Tahapan selanjutnya adalah menyusun dan menetapkan design pelatihan. Design pelatihan yang cermat dan tepat akan mempengaruhi pencapaian kompetensi dari peserta pelatihan. Model ADDIE mempunyai konsep yang sederhana tetapi mewakili keseluruhan system proses pembelajaran. Rencana pelatihan yang disusun menyajikan materi dan tujuan yang disertai dengan metode yang didasarkan pada karakteristik sasran dan jenis materi 
yang disampaikan. Variasi metode pembelajaran diharapkan dapat mempermudah peserta dalam mengadopsi materi lebih cepat. Dan di akhir tahapan adalah pelaksanaan evaluasi yang dilaksanakan baik test formatif maupun sumatif untuk melihat apakah tujuan pelatihan telah tercapai dan apakah pelatihan yang diikuti dapat mengurangi kesenjangan kemampuan dalam memfasilitasi petani dan melakukan komunikasi efektif.

efektif $\begin{gathered}\text { Suatu model pelatihan dianggap } \\ \text { manakala mampu dilandasi }\end{gathered}$ kurikulum, pendekatan dan strategi yang sesuai dengan kebutuhan belajar sasaran didik dan permasalahan-permasalahan yang terjadi di tengah-tengah nya. Untuk itu diperlukan persyaratan khusus dalam membangun sebuah model pelatihan yang efektif dan efesien. Persyaratan tersebut diantaranya adalah kebutuhan belajar peserta pelatihan (sasaran didik, warga belajar dll.) istilah tersebut dalam dunia pendidikan luar sekolah dikenal dengan TNA (Training Needs Assessment), SMA (Subject Matter Analysis) dan ATD (Approaches to Training and Development) (Allison Rossett and Joseph W.Arwady, 1987).
Namun demikian permasalahan ataupun kendala mungkin saja terjadi, kendala utama yang menjadi dasar kemungkinan terjadi kesalahan adalah pada saat analisis kebutuhan latihan. Kendala tersebut dapat diminimalisir dengan membuat perencanaan dengan standart kinerja yang dapat diukur. Peran dari perencana program sangat tinggi dalam menetukan keberhasilan suatu proses pelatihan.

\section{METODE PENYELENGGARAAN}

Peserta pelatihan ini yaitu Penyuluh Pertanian Lapang (PPL) di Kabupaten Malang sebanyak 30 orang pada angkatan pertama dan akan dilanjutkan dengan angkatan selanjutnya sesuai dengan jumlah total PPL di Kab Malang. Pelatihan dilaksanakan selama 5 hari efektif setiap harinya 8 jam. Berikut disampaikan contoh penyelenggaraan pelatihan dengan menetapkan rencana penyelenggaraan dengan materi pokok dasar komunikasi secara operasional sebagai berikut:

Tabel 2. Contoh Penyelenggaraan Pelatihan

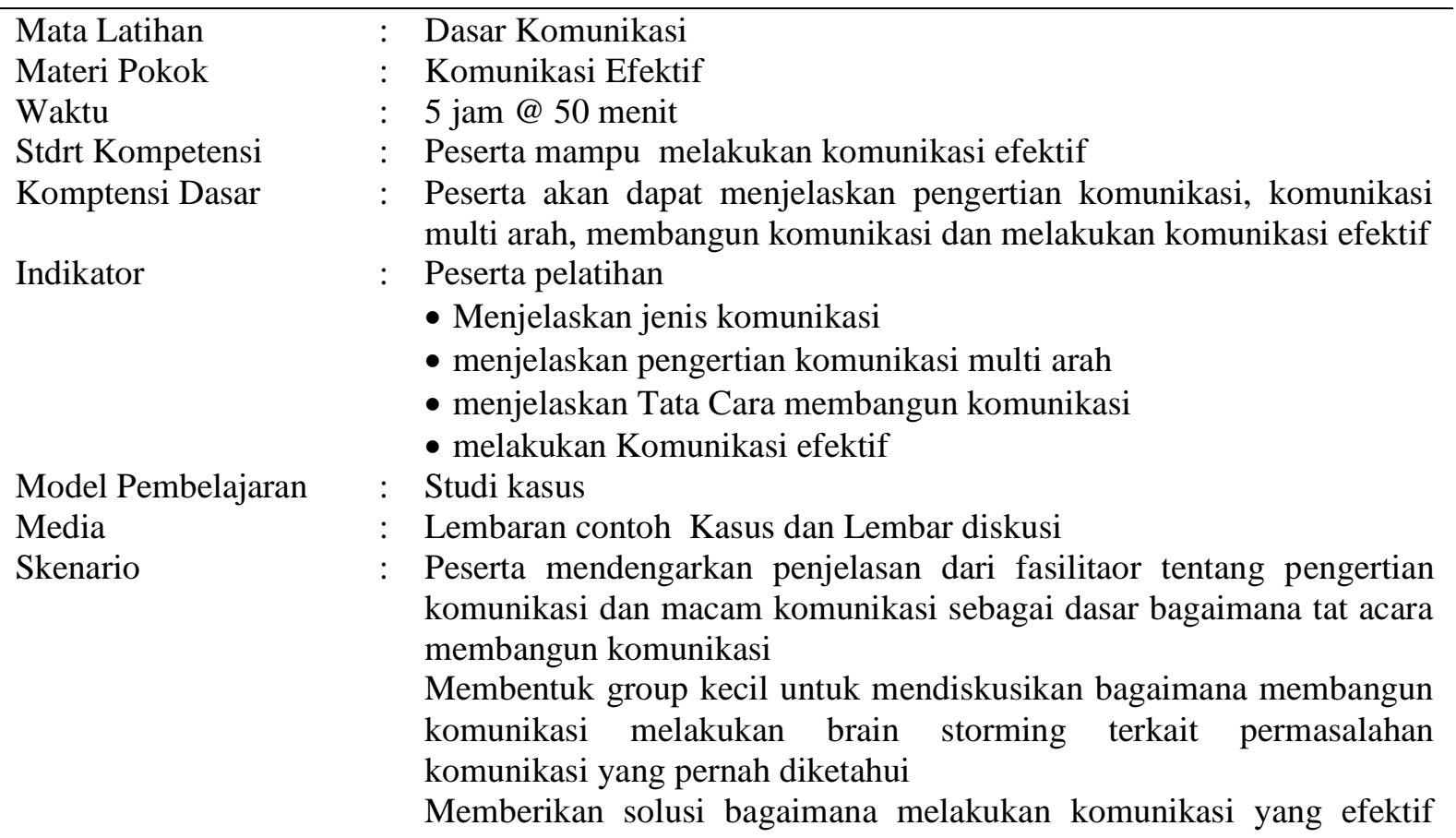




\section{Evaluasi}

Monitoring dan evaluasi dilakukan sebelum, saat dan setelah pelatihan selesai yang meliputi evaluasi perilaku peserta oleh fasilitator, kemajuan berlatih peserta, evaluasi pelatih, kepuasan peserta terhadap proses pelatihan. Untuk mengetahui keberhasilan peserta apakah sudah sesuai dengan tujuan pelatihan dilakukan test formatif, sedangkan test sumatif dilakukan untuk mengetahui apakah kemajuan belajar pada pelatihan yang diikuti sudah dapat mengatasi kekurangan kemampuan kerja (diskrepansi) sebelum peserta mengikuti pelatihan.bbEvaluasi juga dilakukan terhadap pelatihan PPL yang mengukur reaksi dan pemahaman peserta terhadap pelatihan yang telah dilaksanakan. Hasil dari evaluasi ini dapat digunakan untuk menilai efektifitas pelatihan dan memperbaiki pelaksanaan berikutnya.

1. Evaluasi terhadap pelatih dimaksudkan untuk mengetahui tingkat kepuasan peserta terhadap kemampuan pelatih menyampaikan pengetahuan dan/atau keterampilan kepada peserta dengan baik, dapat dipahami dan diserap peserta, meliputi: 1. penguasaan materi 2. ketepatan waktu 3. sistematika penyajian 4 . penggunaan metode dan alat bantu pelatihan 5. empati, gaya dan sikap kepada peserta 6. pencapaian Tujuan Pembelajaran 7. kesempatan tanya jawab 8. kemampuan menyajikan 9. kerapihan pakaian 10. kerjasama antar tim pengajar.

Tabel 3. Instrumen Evaluasi terhadap Pelatih

\begin{tabular}{|l|l|l|l|l|l|l|}
\hline No & \multicolumn{5}{|c|}{ Item yang dinilai } & \multicolumn{5}{|c|}{ SKOR } \\
\cline { 3 - 6 } & & $\mathbf{1}$ & $\mathbf{2}$ & $\mathbf{3}$ & $\mathbf{4}$ & $\mathbf{5}$ \\
\hline 1 & Penguasaan instruktur terhadap materi pelatihan & & & & & \\
\hline 2 & Instruktur memotivasi peserta pelatihan & & & & & \\
\hline
\end{tabular}

2. Evaluasi Terhadap Penyelenggara

Pelatihan

Evaluasi dilakukan oleh peserta terhadap pelaksanaan pelatihan. Obyek evaluasi adalah pelaksanaan administrasi dan akademis yang meliputi: 1. Hubungan peserta dengan pelaksanaan pelatihan 2 . Pelayanan sekretariat terhadap peserta 3. Pelayanan akomodasi 4. Pelayanan konsumsi 5. Pelayanan sarana penunjang pelatihan.

Tabel 4. Instrumen Evaluasi terhadap Pelaksanaan Pelatihan

\section{Fasilitas dan Pelaksanaan Pelatihan}

\begin{tabular}{|l|l|l|l|l|l|l|}
\hline No & \multicolumn{1}{|c|}{ Item yang dinilai } & \multicolumn{5}{|c|}{ SKOR } \\
\cline { 3 - 7 } & & $\mathbf{1}$ & $\mathbf{2}$ & $\mathbf{3}$ & $\mathbf{4}$ & $\mathbf{5}$ \\
\hline 1 & Pelayanan administrasi & & & & & \\
\hline 2 & Pelayanan fasilitas pelatihan & & & & & \\
\hline
\end{tabular}

\section{Materi dan Media Pelatihan}

\begin{tabular}{|c|c|c|c|c|c|c|}
\hline No & Item yang dinilai & 1 & 2 & 3 & 4 & 5 \\
\hline 1 & Materi dibutuhkan oleh peserta pelatihan & & & & & \\
\hline 2 & Kesesuaian materi dengan tujuan pelatihan & & & & & \\
\hline$\ldots$ & Saran.................. & & & & & \\
\hline
\end{tabular}


Evaluasi Peserta, dilakukan untuk mengetahui hasil pelatihan, meliputi: 1 . Kehadiran minimal $90 \%$ 2. Keaktifan dapat ditunjukkan dengan partisipasi aktif selama pelatihan. 3. Penguasaan materi melalui ujian. 4. Pengamatan dan penilaian terhadap tugas yang diberikan.

Tabel 5. Instrumen Evaluasi terhadap Peserta Pelatihan

\begin{tabular}{|c|c|c|c|c|c|c|}
\hline \multicolumn{7}{|c|}{ Nama : DT } \\
\hline No & Item & 1 & 2 & 3 & 4 & 5 \\
\hline \multirow[t]{3}{*}{ I } & Keterampilan & & & & & \\
\hline & 1. Mengidentifikasi masalah & & & & & \\
\hline & 2. Mempraktekkan kemampuan komunikasi & & & & & \\
\hline \multirow[t]{3}{*}{ II } & Pengetahuan & & & & & \\
\hline & 1. Menjelaskan konsep & & & & & \\
\hline & 2. Mendemostrasikan & & & & & \\
\hline \multirow[t]{3}{*}{ III } & Sikap & & & & & \\
\hline & 1. Menyatakan pendapat & & & & & \\
\hline & 2. Mengikuti ketentuan & & & & & \\
\hline
\end{tabular}

Keterangan: 1 - sangat kurang, 2 -agak kurang, 3-neutral, 4-agak baik, 5-sangat baik

\section{KESIMPULAN}

Desain pembelajaran mempengaruhi tujuan pembelajaran sehingga penetapan rencana pembelajaran adalah merupakan faktor penentu keberhasilan suatu program pelatihan. Terdapat banyak model pembelajaran yang dapat digunakan untuk merancang pelatihan salah satunya adalah Model ADDIE. Model ini dipilih karena mempunyai langkah yang sederhana, mudah diterapkan tetapi mewakili keseluruhan proses system pembelajaran. Model pengembangan model pembelajaranADDIE dari lima fase yaitu, Analyze, Design, Develop, Implement, dan Evaluate. Keseluruhan tahapan yang ada pada model ADDIE dapat di implementasikan atau digunakan dalam program pelatihan untuk upaya meningkatkan ketrampilan komunikasi dan teknik fasilitasi yang dirasakan kurang bagi PPL di Kabupaten akan pentingnya partisipasi petani dalam proses penyuluhan.

\section{DAFTAR PUSTAKA}

Achmat, Z. 2010. Theory of planned behavior, masihkah relevan. http://zakarija.staff.umm.ac.id/files/ $\underline{2010 / 12 /}$

Agunga, dkk. 2016. Challanges of Implementing

Extension. Participatory

Communication and Media Ewsearch, Vol 8. No. 1. Sp. 1- May 2016

Branson, R.K. (1975). Interservice procedures for instructional systems development: Executive summary and model. Tallahassee, FL: Center for Educational Technology, Florida State University. (National Technical Information Service). Document Nos. AD-A019 486 to AD-A019490).

Yusran, R. Z. 2006. Penyuluhan Pertanian Partisipatif, Pemberdayaan Petani dan Upaya Percepatan Pembangunan Pertanian. https:// www.academia.edu/21283594/Peny uluhan_Pertanian_Partisipatif

Kartasapoetra, G. 1994. Teknologi Penyuluhan Pertanian. Bina Aksara. Jakarta. 